\title{
The role of plant-crab interaction in structuring microphytobenthic communities in a shallow temperate estuary
}

\author{
Carolina Fernández ${ }^{1,2 *}$, Constanza Da-Rodda ${ }^{3}$, María Cecilia Gauna ${ }^{1}$, María Emilia Croce ${ }^{1,4}$, \\ Elisa R. Parodi ${ }^{1,4}$
}

\author{
${ }^{1}$ CONICET - UNS - Instituto Argentino de Oceanografia \\ (Florida 8000 (Camino La Carrindanga km 7,5) - Bahía Blanca - Buenos Aires - Argentina) \\ ${ }^{2}$ UPSO/CIC - Centro de Emprendedorismo y Desarrollo Territorial Sostenible \\ (Ciudad de Cali N 320 - Bahía Blanca - Buenos Aires - Argentina) \\ ${ }^{3}$ Municipalidad de Bahía Blanca, Comité Técnico Ejecutivo \\ (Av. San Martín 3473 - B8103CEV - Ingeniero White - Buenos Aires - Argentina) \\ ${ }^{4}$ Universidad Nacional del Sur, Departamento de Biología, Bioquímica y Farmacia \\ (Av. Alem 1253 - Bahía Blanca - Buenos Aires - Argentina) \\ *Corresponding author: carofer@criba.edu.ar
}

Microphytobenthos can be defined as the assemblage of microscopic, photosynthetic eukaryotic microalgae and cyanobacteria that live on sediment surfaces in salt marshes, submerged aquatic vegetation beds, intertidal sand and mudflats, and subtidal, illuminated sediments (MacIntyre et al., 1996; Miller et al., 1996). These microorganisms produce macroscopically recognizable microbial mats dominated by cyanobacteria and biofilms of epipelic diatoms, these structures are the result of sediment trapping, binding and precipitation by the extracellular polymeric substances (EPS) produced by the microorganisms (de Winder et al., 1999).

Both diatoms and cyanobacteria excrete EPS, a complex mixture of high-molecular-weight polymers which may consist of $90 \%$ or more of polysaccharides (Hoagland et al., 1993). Diatoms produce EPS when migrating through the sediment in response to light and tidal conditions (Staats et al., 2000). The bacterial EPS secure the cell by forming a capsule around it. This capsule is hardly degradable, protecting the cell from being destroyed in the digestion system of deposit feeders (Decho and Lopez, 1993). It can also have a protective role against dehydration, UV radiation, biomineralization and phagocytosis (Pereira et al., 2011).

Extracellular polymeric substances are present as a matrix or network of strands in sediment interstitial spaces and are considered one of the most important biostabilizing factors, especially on intertidal mudflats sediments. EPS influence the behavior of surficial sediment because they: 1) decrease surface roughness leading to lower

Submitted on: 1/May/2018

Approved on: 9/July/2018

http://dx.doi.org/10.1590/S1679-87592018018906603 turbulent resuspension rates, 2) trap sediment particles, and 3) enhance chemical cohesion between particles due to the higher content of organic matter (Staats et al., 2000).

It is worth mentioning that macrofauna has an important effect on bioturbation, affecting key processes such as organic carbon mineralization (Otani et al., 2010), nutrient dynamics (McHenga and Tsuchiya, 2008), sulfur and iron cycling (Nielsen et al., 2003), sediment texture and particle mixing (Paarlberg et al., 2005). In fact, crab burrowing has been considered one of the major bioturbations affecting physical and chemical processes in salt marshes (Wang et al., 2010). Such soil alterations might further impact microbial activity (Bertics and Ziebis, 2009) and other biotic components.

The dynamics among biological and physical processes in mudflats lead to equilibrium processes (Blanchard et al., 2000; Dyer et al., 2000). Tidal currents are responsible for sediment transport, waves allow sediment deposition or erosion, and these factors interact with the biological components determining whether erosion or deposition is the dominant process. These complex processes, ultimately determine the type and abundance of organisms in the sediment (Dyer et al., 2000).

An association between the estuarine burrowing crab, Neohelice granulata (Dana, 1851) and the halophyte Sarcocornia perennis (Miller) A. J. Scott was described by Perillo and Iribarne (2003) in the muddy salt marshes of the Bahía Blanca Estuary, Argentina. This association has a particular configuration where the plants form a ring surrounding a non-vegetated salt pan densely excavated by the burrowing crab. These ring-shaped configurations are $1.5 \mathrm{~m}$ to $8 \mathrm{~m}$ in diameter and have high water retention at the inner part. The characteristic salt marsh vegetation 
promotes sediment deposition entering the ring at high tide. The soft-sediment mixture produced by crab activity results from their burrowing, deposit-feeding and movement through the sediment (Iribarne et al., 1997).

The particular ring-shaped configuration of the halophyte vegetation is the macroscopic evidence of the changes in the sediment characteristics, such as humidity, salinity and hardness, which occur as a consequence of the plant-crab interaction (Escapa et al., 2007). The objective of the present study was to analyze the epipelic microphytobenthic assemblage structure and characterize the substrata in relation to the spatial distribution of both $S$. perennis and the estuarine crab $N$. granulata.

The research was conducted in a salt marsh $\left(38^{\circ} 43^{\prime} \mathrm{S}\right.$, $\left.62^{\circ} 19^{\prime} \mathrm{W}\right)$ located in the mesotidal Bahía Blanca Estuary in Argentina, in March 2015. The estuary is eutrophic due to the high concentration of organic matter and nutrients supplied from the mainland (Freije and Marcovecchio, 2004).

Given the particular ring-shaped configuration of the halophyte vegetation, four different sampling sites were selected (Figure 1a); namely, N: sites with neither crab burrows nor plants (Figure 1b), P: sites with an isolated plant (Figure 1c), C: sites with crab burrows in the inner part of the ring-shaped configuration (Figure 1d, arrowheads), and P-C: sites with plants and crab burrows in the boundary of the ring-shaped configuration (Figure 1d, arrow). In each sampling site, samples for microphytobenthos (MPB) taxonomic identification and quantification $(n=3)$, sediment grain size determination $(n=3)$ and sediment structure observations by scanning electron microscopy (SEM) (n=3) were randomly taken.

For MPB taxonomic identification and quantification, sediment samples were taken with plastic cylindrical corers (inner diameter $=29 \mathrm{~mm}$, height $=5 \mathrm{~mm}$ ) and preserved in $4 \%$ formaldehyde solution. Cells were separated from the sediment particles by sonication, after which diatoms and cyanobacteria abundance was determined using a Sedgewick-Rafter counting chamber with a Nikon Eclipse 80i light microscope (x 400). To estimate the contribution of each genus to the microphytobenthic community a total of 300 cells were observed in aliquots of samples under a Nikon Eclipse 80i light microscope (x 1000) and their relative abundances were registered. For diatoms identification, samples were processed following Simonsen (1974) and observed by scanning electron microscopy (SEM) in a LEO EVO 40 (Carl Zeiss). Taxa were identified to the lowest taxonomical level possible.
To characterize the sediment structure, blocks of sediment ( $5 \mathrm{~mm} \times 5 \mathrm{~mm}$ ) were cut from each sampling site, fixed in $2.5 \%$ glutaraldehyde $\left(4^{\circ} \mathrm{C}\right.$, one hour), dehydrated in an increasing concentration series of acetone, dried by critical point, coated with gold and observed by SEM (LEO EVO 40, Carl Zeiss).

Sediment grain size was determined with a laser diffraction particle analyzer Malvern Mastersizer 2000. Organic matter was oxidized prior to the analysis by adding $\mathrm{H}_{2} \mathrm{O}_{2}$ with heating and stirring.

One way analysis of variance (ANOVA) was performed to compare the relative abundance of cyanobacteria and diatoms among sampling sites using the software package Infostat (Di Rienzo et al., 2017). A community composition analysis was performed using the software package PRIMER version 6.0 (Clarke and Warwick, 2001). Nonmetric multidimensional scaling (NMDS) was used to order the sampling sites in terms of taxa presence-absence based on a Bray-Curtis similarity matrix, sampling sites that are far apart on the plot are more dissimilar than those that lie near to one another. Analysis of similarity (ANOSIM) with 10,000 permutations (random re-sampling of data) was used to determine if the composition among sampling sites was significantly different. Species contributions to dissimilarity among sampling sites were determined by using similarity percentages analyses (SIMPER).

The main characteristics of each sampling site, including sediment structure and microphytobenthos composition, are summarized in Table 1.

The microphytobenthic community was composed of 80 taxa, including 27 cyanobacteria and 53 diatoms. Comparing the samples from the four sampling sites, the relative abundance of diatoms was statistically higher in the site with crab burrows in the inner part of the ring -namely site $\mathrm{C}$ - and the relative abundance of cyanobacteria was lower $(\mathrm{F}=79.61 ; p<0.001)$ (Figure 2$)$. At sites $\mathrm{N}$, $\mathrm{P}$ and $\mathrm{P}-\mathrm{C}$, the relative abundance of cyanobacteria and diatoms was very similar; however, at site $\mathrm{C}$ the relative abundance of diatoms was much higher than that of cyanobacteria. Nitzschia was the genus that contributed more to the relative abundance of diatoms in the four sampling sites, whereas Rhopalodia was well represented at sites $\mathrm{N}$ and P-C and Navicula at site P. Spirulina was the genus that contributed more to the relative abundance of cyanobacteria at sites $\mathrm{N}$ and $\mathrm{P}$, whereas Lyngbya was well represented at site $\mathrm{P}$. At site $\mathrm{P}-\mathrm{C}$ the genera that more contributed to the relative abundance of cyanobacteria were Oscillatoria, Leptolyngbya and Phormidium (Figure 3). 

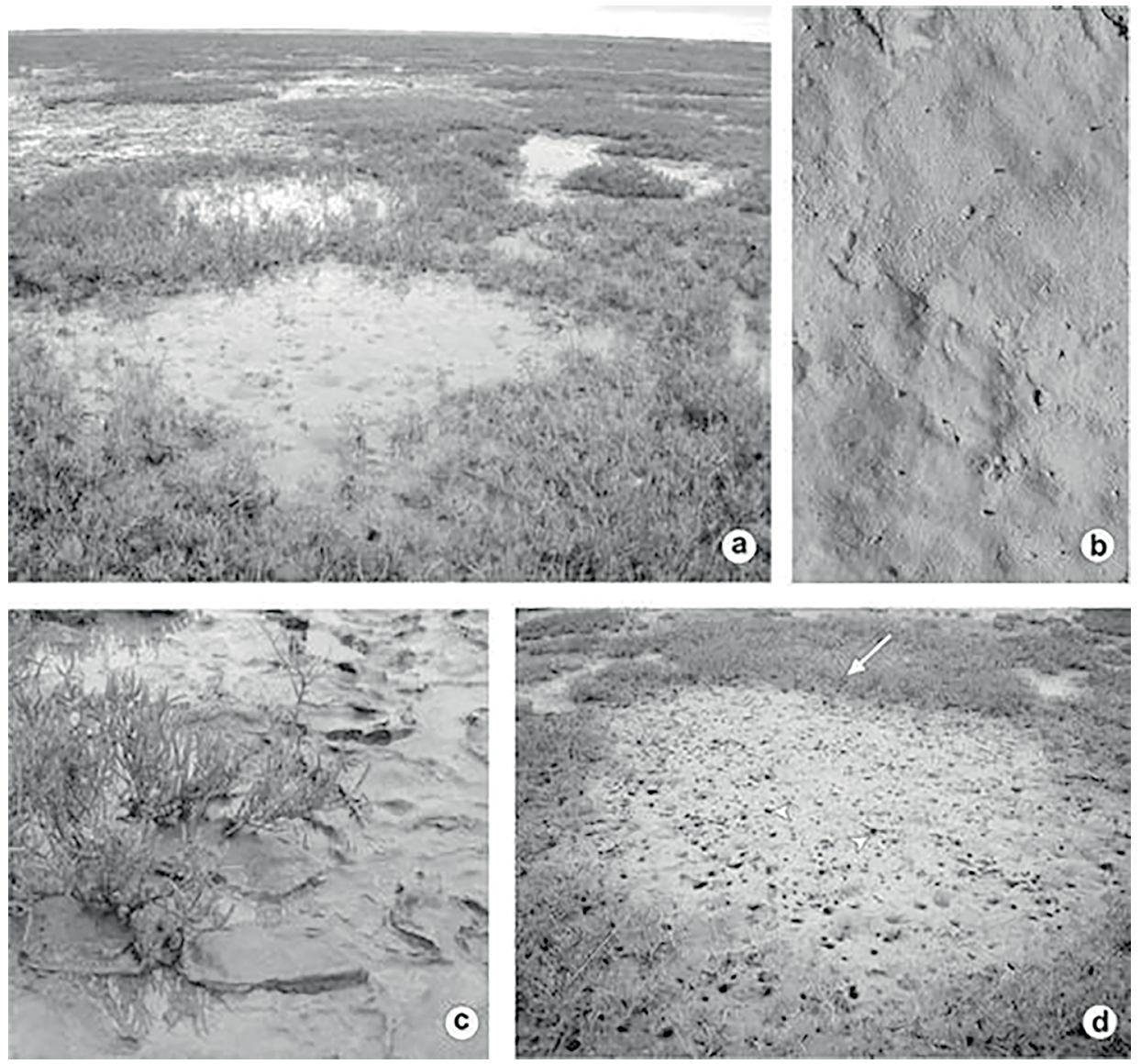

Figure 1. Salt marsh in Bahía Blanca Estuary where the crab Neohelice granulata coexists with the halophyte Sarcocornia perennis. (a) General view of the study area; (b-d) Details of the sampling sites; (b) N: sites with neither crab burrows nor plants; (c) P: sites with an isolated plant; (d) C: sites with crab burrows in the inner part of the ring-shaped configuration (arrowheads) and P-C: sites with plants and crab burrows in the boundary of the ring-shaped configuration (arrow).

NMDS analysis on species composition pooled for all samples clearly separated the assemblages of the four individual sampling sites at a similarity of $60 \%$; however, at a similarity of $30 \%$ sampling sites without crabs -namely $\mathrm{P}$ and $\mathrm{N}$ - were grouped together (Figure 4). Stress values of 0.13 from the MDS plots indicate that the goodness-of-fit was reasonable. The SIMPER results show a detailed list of the main taxa that contributed to the similarity within sampling sites (Table 1). The average similarities within sampling sites were relatively high $(\mathrm{N}=66.39 \%, \mathrm{P}=64.27 \%, \mathrm{C}=64.78 \%$ and $\mathrm{P}-\mathrm{C}=72.38 \%$ ) but were accounted for a large number of taxa with low individual percentage contributions. A highly significant difference among sampling sites communities was also seen in the multivariate comparison of composition (Global $\mathrm{R}=0.9 ; p<0.0001$ ).

The observations made on sediment blocks with scanning electron microscopy showed that EPS displayed an intricate matrix in which sediment particles, detritus and microalgae were caught; however, clear differences in the structure of the sediment among the four sampling sites were found. In fact, at sites N, P and P-C cyanobacterial mats were observed, whereas diatom biofilms were observed at site $\mathrm{C}$ (Figure 5).

At site $\mathrm{N}$ two kinds of microphytobenthic communities were present, the first one composed mainly of the diatom Nitzschia and the cyanobacteria Lyngbya and Leptolyngbya (Figure 5a), and a second more complex one including the diatom Rhopalodia and the cyanobacteria Spirulina and Coleofasciculus. This second community generated greater amounts of EPS which formed a continuous matrix in which the sediment was fully saturated with EPS and void spaces were almost not visible (Figure $5 b$ ). At site $P$ (Figures $5 \mathrm{c}$ and $5 \mathrm{~d}$ ) the sediment was characterized by the development of a continuous matrix of EPS with few interparticle spaces. The surface of the mat was dominated by diatoms, mainly Nitzschia spp. freely deposited on the sediment, and by filaments of Spirulina and Lyngbya. 
Table 1. Sediment characteristics and microphytobenthos composition of the four sampling sites in Bahia Blanca Estuary, Argentina (N: no plant and crab, P: plants, C: crabs and P-C: plants and crabs).

\begin{tabular}{|c|c|c|c|c|}
\hline & \multicolumn{4}{|c|}{ Sampling sites } \\
\hline Descriptors & $\mathrm{N}$ & $\mathrm{P}$ & $\mathrm{C}$ & $\mathrm{P}-\mathrm{C}$ \\
\hline Plant & Absent & Present & Absent & Present \\
\hline Crab burrows & Absent & Absent & Present & Present \\
\hline Grain size* & $87.6 \pm 51.5$ & $64.3 \pm 28.2$ & $<2$ & $57.4 \pm 18.1$ \\
\hline EPS & Continuous matrix & Continuous matrix & Sponge-like web with void spaces & Semi-compacted, similar to $\mathrm{N}$ \\
\hline Number of taxa $* *$ & 36 & 23 & 36 & 54 \\
\hline & $\begin{array}{c}\text { Spirulina subtilissima } \\
\text { Lyngbya confervoides } \\
\text { Phormidium retzii } \\
\text { Johannesbaptistia } \\
\text { pellucida } \\
\text { Delphineis minutissima } \\
\text { Navicula tripunctata } \\
\text { Gomphonema } \mathrm{sp} . \\
\text { Tryblionella apiculata } \\
\text { Nitzschia clausii } \\
\text { Nitzschia } \text { sp. } 2 \\
\text { Rhopalodia musculus }\end{array}$ & $\begin{array}{l}\text { Blennothrix } \\
\text { lyngbyacea } \\
\text { Lyngbya } \mathrm{sp} . \\
\text { Trichocoleus aff. } \\
\text { tenerrimus } \\
\text { Navicula } \\
\text { tripunctata } \\
\text { Cylindrotheca } \\
\text { spaces } \\
\text { Nitzschia clausii }\end{array}$ & $\begin{array}{c}\text { Anabaena } \text { sp. } \\
\text { Kamptonema formosum } \\
\text { Lyngbya confervoides } \\
\text { Leptolyngbya tenuis } \\
\text { Frustulia rhomboides var.spaces } \\
\text { Navicula aff. confervacea } \\
\text { Tryblionema compressa } \\
\text { Nitschia clausii } \\
\text { Nitzschia amphibia } \\
\text { Nitzschia } \text { sp. } 2\end{array}$ & $\begin{array}{c}\text { Anabaenopsis sp. } \\
\text { Spirulina subtilissima } \\
\text { Lyngbya aff. semiplena } \\
\text { Lyngbya spiralis } \\
\text { Phormidium nigroviride } \\
\text { Phormidium corium } \\
\text { Symploca hydnoides } \text { f. minor } \\
\text { Thalassiosira } \mathrm{sp} . \\
\text { Hyalodiscus subtilis } \\
\text { Fragilaria } \text { sp. } \\
\text { Diploneis didyma } \\
\text { Gyrosigma spenceri } \\
\text { Navicula pennata } \\
\text { Navicula cincta } \\
\text { Entomoneis alata } \\
\text { Cymbella cymbiformis } \\
\text { Nitzschia filiformis } \\
\text { Nitzschia scalpelliformis } \\
\text { Rhopalodia gibberula } \\
\text { Rhopalodia constricta }\end{array}$ \\
\hline
\end{tabular}

** Discriminating taxa according to SIMPER results

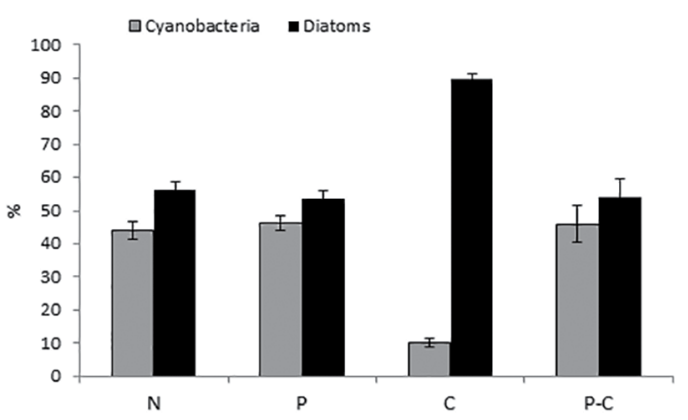

Figure 2. Relative abundance (\%) of diatoms and cyanobacteria in each sampling sites of Bahia Blanca Estuary, Argentina (N: no plant and crab, P: plants, C: crabs and P-C: plants and crabs). The bars represent the standard deviation. ${ }^{*}$ Statistically significant differences $(p<0.001)$.

Both the poor diversity of diatoms and the absence of filaments of Oscillatoria and Leptolyngbya characterized the microphytobenthos of the sites with an isolated plant. The substrate structure of sites P-C had a similar appearance to that described for site $\mathrm{N}$, although the matrix was less

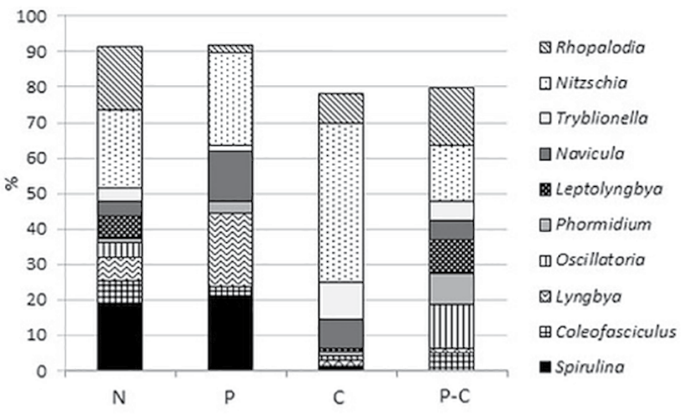

Figure 3. Relative abundance (\%) of genera in sampling sites of Bahia Blanca Estuary, Argentina (N: no plant and crab, P: plants, C: crabs and P-C: plants and crabs) (genera with $>5 \%$ relative abundance).

firm and compact. The surface of the mat was dominated by cyanobacteria and diatoms, which were adhered to lose polymer fibrils like a semi-compacted cohesive substance (Figures 5e and 5f). This microphytobenthic community was characterized by the presence of the diatoms Nitzschia, Tryblionella, Rhopalodia, Navicula, and the cyanobacteria Leptolyngbya, Oscillatoria, Coleofasciculus 


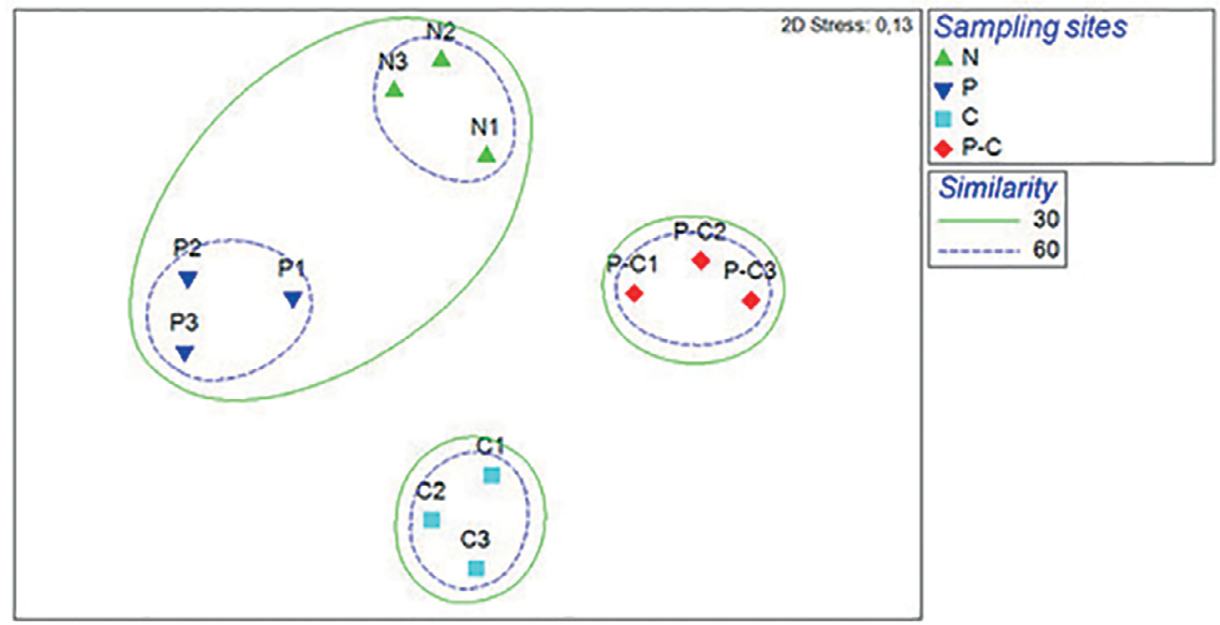

Figure 4. NMDS ordination of sampling sites (N: no plant and crab, P: plants, C: crabs and P-C: plants and crabs) in terms of the microphytobenthic community composition.

and Phormidium. The sites with crab burrows inside a ring of plants (C) presented a significantly different substrate structure from all the other sampling sites. The biofilm showed a much less distinct matrix and was composed mainly by diatoms supported by a sponge-like matrix of EPS. Unlike the cyanobacterial mats, the sediments were not fully saturated with polymer and many void spaces were visible. At this site, EPS were observed as fibrils interlinked forming a web (Figure $5 \mathrm{~g}$ ). This sampling site contained the most fine-grained sediment $(<2 \mu \mathrm{m})$ and Coleofasciculus species were absent.

The presence of the different microphytobenthic species in each sampling site revealed their spatial distribution and the similarity among species associations. Some species, namely Phormidium corium, Symploca hydnoides f. minor and Navicula radiosa, were present only in sites where plants were present; thus, indicating their preference for substrates with a more developed structure (Stal, 1994). In contrast, Tryblionella compressa, Epithemia sorex, Entomoneis alata, Diploneis didyma, Navicula cincta, Cyclotella meneghiniana, Nitzschia sp. 1 and Kamptonema formosum were found in areas where crabs were abundant, indicating their behavior as colonizing species on permanently biodisturbed sediments.

Substrates from each sampling site showed differences in the structure. At sites N, P and P-C cyanobacterial mats were observed, whereas at site $\mathrm{C}$ diatom biofilms were observed. As shown in this study, the structure of the EPS matrix in the biofilms dominated by diatoms was less developed and more irregular than those formed in the presence of cyanobacteria. In cyanobacterial mats, EPS were found as an embedded continuous matrix, whereas in diatom biofilms they developed as a web of spongelike fibrils with void spaces. Such difference has also been observed by de Winder et al. (1999) who attributed it to the different nature of the EPS produced by each kind of organism. In this regard, Soares and Sobral (2009) found that EPS produced by cyanobacteria are less soluble and more adhesive than that of diatoms. Such differences in the EPS structure would determine the mechanical stability of the substrate, resulting in differences in substrate microtopography (Lundkvist et al., 2007).

At site $\mathrm{C}$, a very low abundance of cyanobacteria was observed together with the smaller sediment particle size. According to Stal (2010), cyanobacteria prefer fine sandy sediment $(>60 \mu \mathrm{m})$ as substrate for the formation of microbial mats in coastal areas, whereas sediment consisting of very fine silt and mud are colonized by diatoms. A similar situation was reported by Stal (1994) who suggests that mobile and dynamic sediments cannot be sustained by cyanobacteria. Also, the variations in the size and distribution of grain sediment affect the disposition of some detritivores and the physical properties of the environment, especially when burrows are active (Levinton, 1989).

On the other hand, Coleofasciculus chthonoplastes has been recognized as the dominant cyanobacterium in microbial mats; due to the physical and chemical properties of the filamentous microbial mats produced, it is 

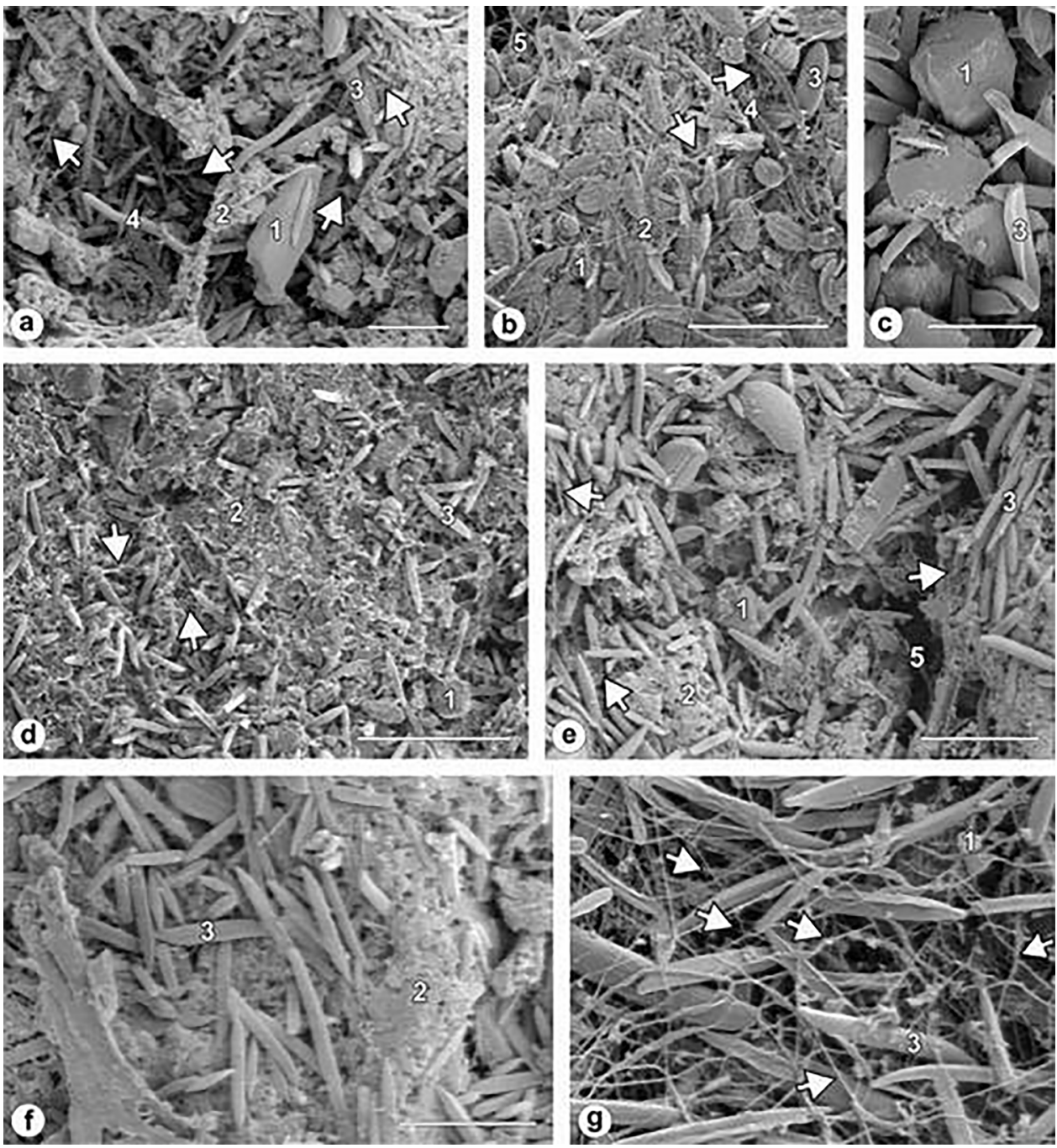

Figure 5. SEM images showing the assemblage of the four sampling sites in Bahia Blanca Estuary (Argentina). (a) N substrate with neither crab burrows nor plants. (b) A more developed community of site N. (c) Detail of superficial cohesive diatoms in P. (d) P substrate with an isolated plant. (e) P-C substrate from the boundary of the ring-shaped configuration. (f) Detail of the compacted matrix of EPS in P-C. (g) C substrate with crab burrows surrounded by plants in a ring-like pattern. Note the sponge-like fibrillar network structure of EPS that formed void spaces. Numbers 1 to 5 denote the different components of the assemblages: (1) sediments particles; (2) EPS mixed with detritus; (3) pennate diatoms; (4) cyanobacteria with thick filaments; (5) cyanobacteria with thin filaments. Arrows denote the EPS fibers. Scale bars: (a) and (e): $100 \mu \mathrm{m}$; (b) and (d): $200 \mu \mathrm{m}$; (c) and (f): $50 \mu \mathrm{m}$; (g): $20 \mu \mathrm{m}$.

considered the origin of sediment stability (Yallop et al., 1994; Bolhuis et al., 2014). The absence of representatives of Coleofasciculus at site C, which by contrast were abundant in the other sampling sites, would account for the observed differences in substrate microtopography.

The high abundance of diatoms at site $\mathrm{C}$ could also have been stimulated by the great amount of water over long periods in these sediments, even at low tide, as was pointed by De Jonge (1985). Another common consequence produced by the water-content of the sediments, particularly in silt and clay, is the redistribution of grains
(Rhoads and Young, 1970; Levinton, 1989), well evidenced at site $\mathrm{C}$.

It is thought that the typical ring-shaped configuration of $S$. perennis is produced by the gradual death of the central plants as a result of changes in the physical and chemical factors produced by crabs when excavating (Perillo and Iribarne, 2003). Borrowing activity has long been known to change sediment characteristics. A common effect of the activity of burrowing deposit feeders is the increase in softness and water content of sediment. Also, the burrows contribute to the accumulation of fine 
particles since trapped sediment with a high percentage of clay during high tide accumulates at the burrow tunnel (Davis, 1993; Botto and Iribarne, 2000). This physical mixture would restrain the formation of large and welldeveloped microbial mats on the superficial sediments of the salt marsh. Then, the death of the central plant could also be associated with permanent modifications in the development of the microphytobenthic succession resulting from the biodisturbing action of crabs.

Considering the significant role of microphytobenthos in biofiltration, recycling of nutrients and sediment stabilization in coastal ecosystems, the distribution patterns of micro- and macro- organisms observed in the present study provides valuable information that should be taken into account in the formulation of integrated management plans, aiming to reduce the ecosystem erosion and contamination.

\section{ACKNOWLEDGEMENTS}

We are thankful to the SEM facility of the Centro Científico Tecnológico Bahía Blanca (CONICET-UNS) for all the SEM images used in this article. CF, MCG and ERP are research members of the Consejo Nacional de Investigaciones Científicas y Técnicas (CONICET). MEC is a postdoctoral fellow from Consejo Nacional de Investigaciones Científicas y Técnicas (CONICET). This work was supported by the Universidad Nacional del Sur under Grant number PGI 24/B234.

\section{REFERENCES}

BERTICS, V. J. \& ZIEBIS, W. 2009. Biodiversity of benthic microbial communities in bioturbated coastal sediments is controlled by geochemical microniches. The ISME Journal, 3, 1269-1285.

BLANCHARD, G. F., PATERSON, D. M., STAL, L. J., RICHARD, P., GALOIS, R., HUET, V., KELLY, J., HONEYWILL, C., DE BROUWER, J., DYER, K., CHRISTIE, M. $\&$ SEGUIGNES, M. 2000. The effect of geomorphological structures on potential biostabilisation by microphytobenthos on intertidal mudflats. Continental Shelf Research, 20, 12431256.

BOLHUIS, H., CRETOIU, M. S. \& STAL, L. J. 2014. Molecular ecology of microbial mats. FEMS Microbiology Ecology, 90, 335-350.

BOTTO, F. \& IRIBARNE, O. 2000. Contrasting effects of two burrowing crabs (Chasmagnathus granulata and Uca uruguayensis) on sediment composition and transport in estuarine environments. Estuarine, Coastal and Shelf Science, 51, 141-151.
CLARKE, K. R. \& WARWICK, R. M. 2001. Change in marine communities: an approach to statistical analysis and interpretation, Plymouth, PRIMER-E, Plymouth Marine Laboratory.

DAVIS, W. R. 1993. The role of bioturbation in sediment resuspension and its interaction with physical shearing. Journal of Experimental Marine Biology and Ecology, $171,187-200$

DE JONGE, V. N. 1985. The occurrence of 'epipsammic' diatom populations: A result of interaction between physical sorting of sediment and certain properties of diatom species. Estuarine, Coastal and Shelf Science, 21, 607-622.

DE WINDER, B., STAATS, N., STAL, L. J. \& PATERSON, D. M. 1999. Carbohydrate secretion by phototrophic communities in tidal sediments. Journal of Sea Research, 42, 131-143.

DECHO, A. W. \& LOPEZ, G. R. 1993. Exopolymer microenvironments of microbial flora: multiple and interactive effects on trophic relationships. Limnology and Oceanography, 38, 1633-1645.

DI RIENZO, J. A., CASANOVES, F., BALZARINI, M. G., GONZALEZ, L., TABLADA, M. \& ROBLEDO, C. W. 2017. InfoStat versión 2017, Córdoba, Universidad Nacional de Córdoba.

DYER, K. R., CHRISTIE, M. C. \& WRIGHT, E. W. 2000. The classification of intertidal mudflats. Continental Shelf Research, 20, 1039-1060.

ESCAPA, M., MINKOFF, D. R., PERILLO, G. M. \& IRIBARNE, O. 2007. Direct and indirect effects of burrowing crab Chasmagnathus granulatus activities on erosion of southwest Atlantic Sarcocornia-dominated marshes. Limnology and Oceanography, 52, 2340-2349.

FREIJE, R. H. \& MARCOVECCHIO, J. 2004. Oceanografía química. In: PICCOLO, M. C. \& HOFFMEYER, M. (eds.) El ecosistema del Estuario de Bahía Blanca. Bahía Blanca: Instituto Argentino de Oceanografía.

HOAGLAND, K. D., ROSOWSKI, J. R., GRETZ, M. R. \& ROEMER, S. C. 1993. Diatom extracellular polymeric substances: function, fine structure, chemistry, and physiology. Journal of Phycology, 29, 537-566.

IRIBARNE, O., BORTOLUS, A. \& BOTTO, F. 1997. Betweenhabitat differences in burrow characteristics and trophic modes in the southwestern Atlantic burrowing crab Chasmagnathus granulata. Marine Ecology Progress Series, 155, 132-145.

LEVINTON, J. S. 1989. Deposit feeding and coastal oceanography. In: LOPEZ, G., TAGHON, G. \& LEVINTON, J. (eds.) Ecology of Marine Deposit Feeders. New York: SpringerVerlag.

LUNDKVIST, M., GANGELHOF, U., LUNDING, J. \& FLINDT, M. R. 2007. Production and fate of extracellular polymeric substances produced by benthic diatoms and bacteria: A laboratory study. Estuarine, Coastal and Shelf Science, 75, 337346.

MACINTYRE, H. L., GEIDER, R. J. \& MILLER, D. C. 1996. Microphytobenthos: The ecological role of the "secret garden" of unvegetated, shallow-water marine habitats. I. Distribution, abundance and primary production. Estuaries, 19, 186-201. 
MCHENGA, I. S. S. \& TSUCHIYA, M. 2008. Nutrient dynamics in mangrove crab burrow sediments subjected to anthropogenic input. Journal of Sea Research, 59, 103-113.

MILLER, D. C., GEIDER, R. J. \& MACINTYRE, H. L. 1996. Microphytobenthos: The ecological role of the "secret garden" of unvegetated, shallow-water marine habitats. II. Role in sediment stability and shallow-water food webs. Estuaries, $19,202-212$.

NIELSEN, O. I., KRISTENSEN, E. \& MACINTOSH, D. J. 2003. Impact of fiddler crabs (Uca spp.) on rates and pathways of benthic mineralization in deposited mangrove shrimp pond waste. Journal of Experimental Marine Biology and Ecology, $289,59-81$.

OTANI, S., KOZUKI, Y., YAMANAKA, R., SASAOKA, H., ISHIYAMA, T., OKITSU, Y., SAKAI, H. \& FUJIKI, Y. 2010. The role of crabs (Macrophthalmus japonicus) burrows on organic carbon cycle in estuarine tidal flat, Japan. Estuarine, Coastal and Shelf Science, 86, 434-440.

PAARLBERG, A. J., KNAAPEN, M. A. F., DE VRIES, M. B., HULSCHER, S. J. M. H. \& WANG, Z. B. 2005. Biological influences on morphology and bed composition of an intertidal flat. Estuarine, Coastal and Shelf Science, 64, 577-590.

PEREIRA, S., MICHELETTI, E., ZILLE, A., SANTOS, A., MORADAS-FERREIRA, P., TAMAGNINI, P. \& DE PHILIPPIS, R. 2011. Using extracellular polymeric substances (EPS)-producing cyanobacteria for the bioremediation of heavy metals: do cations compete for the EPS functional groups and also accumulate inside the cell? Microbiology, 157, 451-458.

PERILLO, G. M. E. \& IRIBARNE, O. O. 2003. Processes of tidal channels develop in salt and freshwater marshes. Earth Surface Processes and Landforms, 28, 1473-1482.
RHOADS, D. C. \& YOUNG, D. K. 1970. The influence of depositfeeding organisms on sediment stability and community trophic structure. Journal of Marine Research, 28, 150-178.

SIMONSEN, R. 1974. The diatom plankton of the Indian Ocean Expedition of $R / V$ “Meteor" 1964-1965. Meteor Forschungsergebnisse, Berlin, Gebrüder Bornträger.

SOARES, C. \& SOBRAL, P. 2009. Bioturbation and erodibility of sediments from the Tagus Estuary. Journal of Coastal Research, 56, 1429-1433.

STAATS, N., STAL, L. J. \& MUR, L. R. 2000. Exopolysaccharide production by the epipelic diatom Cylindrotheca closterium: effects of nutrient conditions. Journal of Experimental Marine Biology and Ecology, 249, 13-27.

STAL, L. J. 1994. Microbial mats in coastal environments. In: STAL, L.J. \& CAUMETTE, P. (eds.) Microbial mats: structure, development and environmental significance. Berlin, Springer-Verlag.

STAL, L. J. 2010. Microphytobenthos as a biogeomorphological force in intertidal sediment stabilization. Ecological Engineering, 36, 236-245.

WANG, J. Q., ZHANG, X. D., JIANG, L. F., BERTNESS, M. D., FANG, C. M., CHEN, J. K., HARA, T. \& LI, B. 2010. Bioturbation of burrowing crabs promotes sediment turnover and carbon and nitrogen movements in an estuarine salt marsh. Ecosystems, 13, 586-599.

YALLOP, M. L., DE WINDER, B., PATERSON, D. M. \& STAL, L. J. 1994. Comparative structure, primary production and biogenic stabilization of cohesive and non-cohesive marine sediments inhabited by microphytobenthos. Estuarine, Coastal and Shelf Science, 39, 565-582. 